\title{
IMPLEMENTASI PERATURAN PEMERINTAH REPUBLIK INDONESIA NOMOR 28 TAHUN 2012 TENTANG KEARSIPAN PADA LEMBAGA LAYANAN PENDIDIKAN TINGGI WILAYAH II
}

\author{
Sunarto \\ Dosen Tetap STIA Satya Negara \\ Email: sunarto1974@gmail.com
}

\begin{abstract}
Filing is a very important part of office work. Accurate written information must be available when necessary so that the office can provide effective services. Archives are needed in administration because archives are the center of memory for every activity in an office. Without archives, it is impossible for an archivist to remember all records and documents completely. The data analysis technique in this study uses inductive logic. The analysis will move from something specific or specific, namely those obtained in the field, towards a finding that is general in nature and can draw a conclusion. The results show that the implementation of the Republic of Indonesia Government Regulation Number 28 of 2012 concerning Archives at the Region II Higher Education Service Institution has not been carried out properly, the archives are still partially stored, this is due to insufficient human resources and a special archive room is not yet available.
\end{abstract}

Keywords: Implementation and Archives

\begin{abstract}
ABSTRAK
Kearsipan merupakan bagian pekerjaan kantor yang sangat penting. Informasi tertulis yang tepat harus tersedia apabila diperlukan agar kantor dapat memberikan pelayanan yang efektif, Kearsipan sangat dibutuhkan dalam pelaksanaan administrasi karena arsip merupakan pusat ingatan bagi setiap kegiatan dalam suatu kantor. Tanpa arsip tidak mungkin seorang petugas arsip dapat mengingat semua catatan dan dokumen secara lengkap. Teknik analisa data pada penelitian ini menggunakan logika induktif. Analisis akan bergerak dari sesuatu hal yang khusus atau spesifik, yaitu yang diperoleh di lapangan, ke arah suatu temuan yang bersifat umum dan dapat menarik suatu kesimpulan. Hasil penelitian menunjukkan bahwa Implementasi Peraturan Pemerintah Republik Indonesia Nomor 28 Tahun 2012 Tentang Kearsipan Pada Lembaga Layanan Pendidikan Tinggi Wilayah II belum terlaksana dengan baik, arsip masih disimpan perbagian hal ini disebabkan sumber daya manusia yang ada belum mencukupi dan ruangan khusus arsip belum tersedia.
\end{abstract}

Kata Kunci: Implementasi dan Kearsipan

\section{PENDAHULUAN}

Kearsipan merupakan bagian pekerjaan kantor yang sangat penting. Informasi tertulis yang tepat harus tersedia apabila diperlukan agar kantor dapat memberikan pelayanan yang efektif, Kearsipan sangat dibutuhkan dalam pelaksanaan administrasi karena arsip merupakan pusat ingatan bagi setiap kegiatan dalam suatu kantor. Tanpa arsip tidak mungkin seorang petugas arsip dapat mengingat semua catatan dan dokumen secara lengkap.

Efektivitas pengelolaan kearsipan pada suatu kantor kemungkinan dipengeruhi pula oleh pegawai yang bekerja pada unit kearsipan, sarana atau fasilitas yang dipergunakan dalam membantu 
pengelolaan arsip dan dana yang tersedia untuk pemeliharaan arsip tersebut.

Keperluan akan pengelolaan arsip yang baik dan benar sangat diharapkan oleh organisasi dalam menunjang efektivitas kerja dan kelancaran adminitrasi perkantoran, Pengelolaan arsip akan di rasakan bermanfaat oleh organisasi untuk menjadi bahan rujukan dalam pengambilan kebijakan-kebijakan strategis perusahaan atau instansi dengan meperhatikan data-data yang tersimpan.

Administrasi kearsipan memegang peranan penting dalam suatu organisasi, manajemen dan administrasi, arsip merupakan suatu ingatan dalam setiap kegiatan, tanpa arsip tidak mungkin seseorang mengingat segala dokumen catatan yang begitu kompleks. Oleh sebab itu, pengelolaan kearsipan selalu dikaitkan dengan surat, wakat, record, dan dokumen lainya.

Fungsi arsip sebagai ingatan, pusat informasi dan seumber sejarah perlu dikelola dengan baik agar dapat mempelancar seluruh kegiatan dan proses pekerjaan kantor yang berhasil guna dan berdaya guna. Dalamhal ini unit kearsipan harus senantiasa siap untuk memberikan pelayanan informasi yang akurat dalam memecahkan masalah administrasi pada umumnya dan dalam manajemen kersipan pada khususnya.

Namun pada kenyataannya, sebagaian pegawai masaih enggan untuk menerima tugas - tugas kearsipan mereka memandang bahwa unit kearsipan pada setiap kantor adalah tempat yang membosankan. Adanya pandangan yang seperti ini menunjukan bahwa pegawai kurang menyadari akan pentingnya pengelolaaan asrip dalam suatu kantor dalam menunjang efektifitas suatu pekerjaan.

Pemikiran-pemikiran seperti inilah yang harus dihindari dan sebaiknya ditanamkan rasa cinta terhadap arsip sehingga manusia sebagai faktor penentu dalam kearsipan yang berdaya guna dan berhasil guna dapat tercapai dengan baik.

Keperluan akan pengelolaan arsip yang baik dan benar sangat diharapkan oleh organisasi dalam menunjang efektivitas kerja dan kelancaran administrasi perkantoraan, pengelolaan arsip akan di rasakan bermanfaat oleh organisasi untuk menjadi bahan rujukan dalam pengambilan kebijakan-kebijakan strategis perusahaan atau instansi dengan memperhatikan data-data yang tersimpan.

Setiap instansi pemerintah mempunyai sistem kearsipan tersendiri baik itu azas sentralisasi, azas desentralisasi, maupun azas campuran. Akan tetapi banyak kantor-kantor yang menggunakan sistem kearsipan desentralisasi yang artinya setiap bagian dalam instansi pemerintah memilik arsip sendiri. Misalnya bagian kepegawaian. Begitu juga di bagian-bagian lain, hal ini di karenakan apabila pimpinan membutuhkan suatu arsip, misalnya yang berhubungan dengan kepegawaian makan akan mudah dan eapat untuk menemukannya atau lebih efektif dan efesien. Tetapi pada juga instansi pemerintah yang menggunakan system kearsipan.

\section{LANDASAN TEORI}

Ada beberapa teori yang digunakan penulis adalah

\section{A. Pengertian Implementasi}

Implementasi adalah pelaksanaan atau penerapan, dalam 
kamus Besar Bahasa Indonesia (KBBI), dan pengertian secara umum, Implementasi adalah tindakan atau pelaksanaan dari sebuah rencana yang telah disusun secara matang, cermat dan terperinci, jadi implementasi dilakukan jika sudah ada perencanaan yang baik dan matang, atau sebuah rencana yang telah disusun jauh-jauh hari sebelumnya, sehingga sudah ada kepastian dan kejelasan akan rencana tersebut.

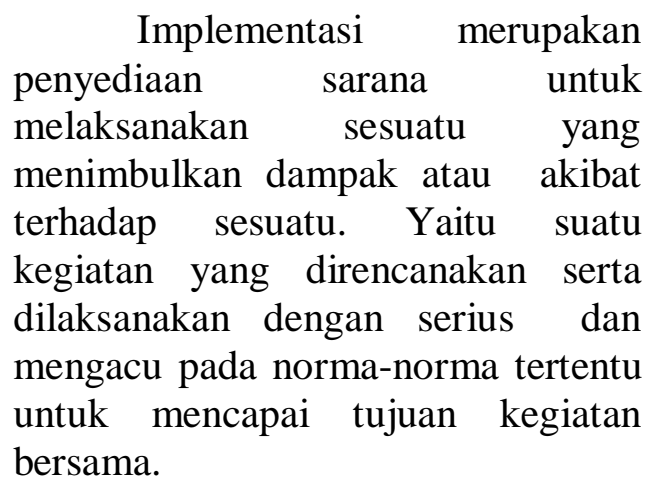

\section{B. Pengertian Implementasi menurut para ahli}

Pendapat Cleaves yang dikutip (dalam Wahab 2008;187), yang secara tegas menyebutkan bahwa: Implementasi itu mencakup "Proses bergerak menuju tujuan kebijakan dengan cara langkah administratif dan politik". Keberhasilan atau kegagalan implementasi sebagai demikian dapat dievaluasi dari sudut kemampuannya secara nyata dalam meneruskan atau mengoperasionalkan programprogram yang telah dirancang sebelumya.

Menurut Mazmanian dan Sebastiar (dalam Wahab, 2008: 68) Implementasi adalah pelaksanaan keputusan kebijakan dasar, biasanya dalam bentuk undang-undang, namun dapat pula berbentuk perintah-perintah atau keputusankeputusan eksekutif yang penting atau keputusan badan peradilan.

\begin{abstract}
Menurut Van Meter dan Van Horn (dalam Wahab, 2008: 65) Implementasi adalah tindakantindakan yang dilakukan baik oleh individu-individu/pejabat-pejabat atau kelompok-kelompok pemerintah atau swasta yang diarahkan pada tercapainya tujuan-tujuan yang telah digariskan dalam keputusan kebijakan.
\end{abstract}

Dari definisi menurut para ahli diatas, dari adanya suatu kebijakan atau program, untuk mencapai tujuan tersebut maka suatu kebijakan membutuhkan masukan- masukan kebijakan, Masukan kebijkan yang umum dipakai untuk mencapai tujuan kebijakan publik adalah berupa anggaran, misalnya Anggaran Pendapatan dan Belanja Negara APBN dan Anggaran Pendapatan Belanja Daerah (APBD) untuk, membiayai berbagai kebijakan yang dirancang/dirumuskan oleh Pemerintah pusat, daerah, baik yang di provinsi / kabupaten/kota. Sebaliknya keseluruhan proses implementasi kebijakan dapat dievaluasi dengan cara mengukur atau membandingkan antara hasil akhir dari program-program tersebut dengan tujuan-tujuan kebijakan.

Dengan demikian, proses dari implementasi baru akan dimulai apabila tujuan-tujuan dari kebijakan telah ditetapkan, sarana dan prasarana pendukung, sumber daya manusia ( pelaku/agen), serta alat kontrol pelaksanaan kebijakan telah ditetapkan dan dialokasikan untuk mencapai tujuan, untuk mengimplemetasi kan kebijakan yang telah ditetapkan, maka diperlukan adanya tahap-tahap implementasi. 


\section{Model - Model Implementasi Kebijakan Menurut Para Ahli}

1. Teori George C.Edwards III ( dalam Agustino (2016:136141)

Teori implementasi kebijakan yang berperspektif top-down dikembangkan oleh George C. Edward III. Edward III menamakan model implementasi kebijakan publiknya dengan istilah Direct and Indirect Impact on Implementation. Dalam pendekatan yang diteoremakan oleh Edward III, terdapat empat variabel yang sangat menentukan keberhasilan implementasi suatu kebijakan, yaitu: (i) komunikasi; (ii) sumber daya; (iii) disposisi; dan (iv) struktur birokrasi.

Variabel pertama yang mempengaruhi keberhasilan implementasi suatu kebijakan, menurut Edward III, adalah komunikasi. Komunikasi, menurutnya, sangat menentukan keberhasilan pencapaian tujuan dari implementasi kebijakan publik. Implementasi yang efektif terjadi apabila para pembuat keputusan sudah mengetahui apa yang akan mereka kerjakan. Pengetahuan atas apa yang akan mereka kerjakan dapat berjalan bila komunikasi berjalan dengan baik sehingga setiap keputusan kebijakan dan peraturan implementasi harus ditransmisikan (atau dikomunikasikan) kepada bagian personalia yang tepat. Selain itu, kebijakan yang dikomunikasikan pun harus tepat, akurat, dan konsisten. Komunikasi (atau pentransmisian informasi) diperlukan agar para pembuat keputusan di dan para implementor akan semakin konsisten dalam melaksanakan setiap kebijakan yang akan diterapkan dalam masyarakat.
Terdapat 3 (tiga) indikator yang dapat dipakai (atau digunakan) dalam mengukur keberhasilan variabel komunikasi tersebut di atas, yaitu:
a. Transmisi;
penyaluran
komunikasi yang baik akan
dapat menghasilkan suatu implementasi yang baik pula.
Seringkali yang terjadi dalam penyaluran komunikasi adalah adanya salah pengertian (miskomunikasi), hal ini disebabkan karena komunikasi telah melalui beberapa tingkatan birokrasi sehingga apa yang diharapkan terdistorsi di tengah jalan.

b. Kejelasan; komunikasi yang diterima oleh para pelaksana kebijakan (street-levelbureuacrats) haruslah jelas dan tidak membingungkan (tidak ambigu). Ketidakjelasan pesan kebijakan tidak selalu menghalangi implementasi, pada tataran tertentu, namun para pelaksana membutuhkan kejelasan informasi dalam melaksanakan kebijakan agar tujuan yang hendak dicapai dapat diraih sesuai konten kebijakan.

c. Konsistensi; perintah yang diberikan dalam pelaksanaan suatu komunikasi haruslah konsisten (untuk diterapkan dan dijalankan). Ini karena jika perintah yang diberikan sering berubah-ubah, maka dapat menimbulkan kebingungan bagi pelaksana di lapangan.

d.

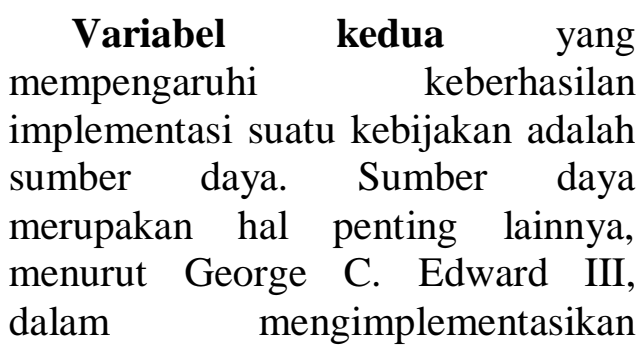


kebijakan. Indikator sumber-sumber daya terdiri dari beberapa elemen, yaitu:

a. Staf; sumber daya utama dalam implementasi kebijakan adalah staf atau sumber daya manusia (SDM). Kegagalan yang sering terjadi dalam implementasi kebijakan salah satunya disebabkan oleh karena staf yang tidak mencukupi, memadai, ataupun tidak kompeten di bidangnya. Penambahan jumlah staf atau implementor saja tidak mencukupi, tetapi diperlukan pula kecukupan staf dengan keahlian serta kemampuan yang diperlukan (kompeten dan kapabilitas) dalam mengimplementasikan

kebijakan atau melaksanakan tugas yang diinginkan oleh kebijakan itu sendiri.

b. Informasi; dalam implementasi kebijakan, informasi mempunyai dua bentuk yaitu: (i) informasi yang berhubungan dengan cara melaksanakan kebijakan. Implementor harus mengetahui apa yang harus mereka lakukan di saat mereka diberi perintah untuk melakukan tindakan. Dan (ii) informasi mengenai data kepatuhan dari para pelaksana terhadap peraturan dan regulasi pemerintah yang telah ditetapkan. Implementor harus mengetahui apakah orang lain yang terlibat di dalam pelaksanaan kebijakan tersebut patuh terhadap hukum.

c. Wewenang; pada umumnya kewenangan harus bersifat formal agar perintah dapat dilaksanakan. Kewenangan merupakan otoritas atau legitimasi bagi para pelaksana dalam-melaksanakan kebijakan yang ditetapkan secara politik. Ketika wewenang itu nihil, maka kekuatan para implementor di mata publik tidak terlegitimasi, sehingga dapat menggagalkan proses implementasi kebijakan. Tetapi, dalam konteks yang lain, ketika wewenang formal tersebut ada, maka sering terjadi kesalahan dalam melihat efektivitas kewenangan. Di satu pihak, efektivitas kewenangan diperlukan dalam pelaksanaan implementasi kebijakan; tetapi di sisi lain, efektifitas akan menyurut manakala wewenang diselewengkan oleh para pelaksana demi kepentingannya sendiri atau demi kepentingan kelompoknya.

d. Fasilitas; fasilitas fisik juga merupakan faktor penting dalam implementasi kebijakan. Implementor mungkin memiliki staf yang mencukupi, mengerti apa yang harus dilakukannya, dan memiliki wewenang untuk melaksanakan tugasnya, tetapi tanpa adanya fasilitas pendukung (sarana dan prasarana) maka implementasi kebijakan tersebut tidak akan berhasil.

Variabel ketiga yang mempengaruhi tingkat keberhasilan implementasi kebijakan publik, bagi George C. Edward III, adalah disposisi. Disposisi atau 'sikap dari pelaksana kebijakan' adalah faktor penting ketiga dalam pendekatan mengenai pelaksanaan suatu kebijakan publik. Jika pelaksanaan suatu kebijakan ingin efektif, maka para pelaksana kebijakan tidak hanya harus mengetahui apa yang akan dilakukan tetapi juga harus memiliki 
kemampuan untuk melaksanakannya, sehingga dalam praktiknya tidak terjadi bias.

Hal-hal penting yang perlu dicermati pada variabel disposisi, menurut Edward III, adalah:

a. Efek Disposisi; disposisi atau sikap para pelaksana akan menimbulkan hambatanhambatan yang nyata terhadap implementasi kebijakan bila personil yang ada tidak melaksanakan kebijakankebijakan yang diinginkan oleh pejabatpejabat tinggi. Oleh karena itu, pemilihan dan pengangkatan personil pelaksana kebijakan haruslah orang-orang yang memiliki dedikasi pada kebijakan yang telah ditetapkan; lebih khusus lagi pada kepentingan warga.

b. Melakukan Pengaturan Birokrsi (stffing the bureaucracy); dalam konteks ini Edward III mensyaratkan bahwa implementasi kebijakan harus dilihat juga dalam halpengaturan birokrasi. Ini merujuk pada penunjukan dan pengangkatan staf dalam birokrasi yang sesuai dengan kemampuan, kapabilitas, dan kompetensinya. Selain itu, pengaturan birokrasi juga bermuara pada 'pembentukan' sistem pelayanan publik yang optimal, penilaian personil dalam bekerja, hingga metode bypassing personil

c. Insentif; Edward III menyatakan bahwa salah satu teknik yang disarankan untuk mengatasi masalah kecenderungan para pelaksana adalah dengan memanipulasi insentif. Pada umumnya orang bertindak menurut kepentingan mereka sendiri, maka memanipulasi insentif oleh para pembuat kebijakan mempengaruhi tindakan para pelaksana kebijakan. Dengan cara menambah keuntungan atau biaya tertentu mungkin akan menjadi faktor pendorong yang membuat para pelaksana kebijakan melaksanakan perintah dengan baik. Hal ini dilakukan sebagai upaya memenuhi kepentingan pribadi (self interest) atau organisasi.

Variabel keempat, menurut George C. Edward III, yang mempengaruhi tingkat keberhasilan implementasi kebijakan publik adalah struktur birokrasi. Walaupun sumber-sumber daya untuk melaksanakan suatu kebijakan tersedia, atau para pelaksana kebijakan mengetahui apa yang seharusnya dilakukan, dan mempunyai keinginan untuk melaksanakan suatu kebijakan, kemungkinan kebijakan tersebut tidak dapat terlaksana atau terealisasi karena terdapat kelemahan dalam struktur birokrasi. Kebijakan yang begitu kompleks menuntut adanya kerjasama banyak orang, ketika struktur birokrasi tidak kondusif pada kebijakan yang tersedia, maka hal ini akan menyebabkan sumber-sumber daya menjadi tidak efektif dan tidak termotivasi sehingga menghambat jalannya kebijakan. Birokrasi sebagai pelaksana sebuah kebijakan harus dapat mendukung kebijakan yang telah diputuskan secara politik dengan jalan melakukan koordinasi dengan baik.

Dua karakteristik, menurut Edward III, yang dapat mendongkrak kinerja struktur birokrasi atau organisasi ke arah yang lebih baik adalah: 
a. Membuat Standar Operating Procedures (SOPs) yang lebih fleksibel; SOPs adalah suatu prosedur atau aktivitas terencana rutin yang memungkinkan para pegawai (atau pelaksana kebijakan seperti aparatur, administratur, atau birokrat) untuk melaksanakan kegiatankegiatannya pada setiap harinya (days-todays politics) sesuai dengan standar yang telah ditetapkan (atau standar minimum yang dibutuhkan warga).

b. Melaksanakan fragmentasi, tujuannya untuk menyebar tanggungjawab pelbagai aktivitas, kegiatan, atau program pada beberapa unit kerja yang sesuai dengan bidangnya masing-masing. Dengan terfragmentasinya struktur birokrasi, maka implementasi akan lebih efektif karena dilaksanakan oleh organisasi yang kompeten dan kapabel.

\section{Jenis-Jenis Arsip}

Sugiarto

berpendapat bahwa ada 8 (delapan) jenis arsip yang mempunyai fungsi yang berbeda-beda. Adapun 8 (delapan) jenis arsip tersebut antara lain:

1. Arsip menurut subyek atau isinya Arsip menurut subyek atau isinya merupakan arsip yang dikelompokkan berdasarkan isi atau subjek dari surat yang disimpan. Contoh arsip ini adalah riwayat hidup pegawai, laporan keuangan, surat penawaran, daftar hadir siswa, dll.

2. Arsip menurut bentuk dan wujud fisik
Arsip menurut bentuk dan wujud fisik merupakan arsip yang dikelompokkan berdasarkan fisik dari surat atau fisik lainnya dari arsip itu sendiri. Contoh dari arsip ini adalah surat, pita rekaman, mikrofilm, disket, compact disk (CD), dll.

3. Arsip menurut nilai atau kegunaannya

Arsip menurut nilai atau kegunaannya merupakan arsip yang mempunyai nilai atau kegunaannya. Contoh dari arsip ini adalah undangan, surat keputusan, akte pendirian perusahaan, dll.

4. Arsip menurut sifat kepentingannya

Arsip menurut sifat kepentingannya merupakan arsip yang mempunyai sifat kepentingan atau urgensi baik berupa vital, penting, berguna sampai tidak berguna. Contoh dari arsip ini adalah surat undangan, akte pendirian perusahaan, daftar gaji, dll.

5. Arsip menurut fungsinya

Arsip menurut fungsinya didasarkan menjadi dua yaitu arsip dinamis yang sering digunakan sehari-hari dan arsip statis yang tidak digunakan sehari-hari dan arsip statis yang tidak digunakan lagi sehari-hari.

6. Arsip menurut tempat atau tingkat pengelolaannya

Arsip menurut tempat atau tingkat pengelolaannya merupakan pengelolaan atau tempat yang akan menyimpan arsip misalnya arsip pusat yang biasa disebut dengan sentralisasi atau arsip unit yang biasa disebut dengan desentralisasi atau berada di unit-unit setiap organisasi. 
7. Arsip menurut keasliannya

Arsip menurut keasliannya merupakan arsip asli yang langsung dibuat dengan hentakan mesin tik atau disebut dengan dokumen utama yang benar-benar memiliki keaslian yang tinggi.

8. Arsip menurut kekuatan hukum Arsip menurut kekuatan hukum merupakan arsip yang dilihat dari bukti keasliannya. Arsip yang memiliki nilai keasliannya yaitu arsip yang mempunyai tanda tangan asli dari atasan atua pimpinan suatu organisasi sebagai bukti sahnya arsip tersebut.

\section{E. Peralatan dan Perlengkapan Arsip}

Seperti dikatakan oleh Sugiarto (2015:16) bahwa terdapat berbagai jenis peralatan dan perlengkapan arsip yang digunakan dalam proses kearsipan. Peralatan dan perlengkapan yang digunakan tergantung kepada kebutuhan setiap organisasi pada saat mengarsipkan. Adapun perlatan dan perlengkapan yang digunakan antara lain:

a. Peralatan arsip

Peralatan arsip sering digunakan untuk menyimpan arsip dalam jumlah yang banyak. Peralatan dapat dikelompokkan menjadi 3 (tiga) jenis yaitu Alat penyimpanan tegak seperti lemari arsip. Lemari arsip dapat berupa 2 laci, 3 laci, 4 laci, 5 laci dan 6 laci yang mempunyai kegunaan sebagai tempat gantungan folder. Alat penyimpanan menyamping merupakan alat yang sama seperti alat penyimpanan tegak namun bedanya diletakkan menyamping bukan tegak. Alat ini biasa disebut dengan file lateral. Alat penyimpanan berat merupakan alat yang mempunyai fugnsi menyimpan arsip lebih banyak dan dapat digerakkan kedepan atau kebelakagn dan sering disebut dengan Roll O-pack.

b. Perlengkapan arsip

Penyimpanan arsip tidak hanya membutuhkan peralatan namun juga memerlukan perlengkapan yang dapat mendukung penyimpanan arsip. Perlengkapan arsip yang sering digunakan antara lain Map atau folder merupakan tempat yang berfungsi sebagai menyimpan arsip seperti map jepit, bantex, dll. Map berfugnsi sebagai tempat menyimpan arsip sesuati dengan subjek atau perihal surat. Pembatas atau guide merupakan penunjuk sekaligus tempat berkas-berkas disimpan dan pemisah antara berkasberkas.

Sedarmayanti $\quad$ (2008:110) menambahkan dalam arsip dapat diselenggarakan dengan menggunakan:

1. Buku agenda

2. Pencatatan surat masuk dan surat keluar dapat dipisahkan dengan menggunakan buku agenda surat masuk dan buku agenda surat keluar, yang biasanya dibedakan pula tahunnya.

3. Kartu kendali

4. Kartu kendali adalah helai tipis berukuran $10 \times 15 \mathrm{~cm}$ berisi kolom-kolom untuk mencatat surat masuk dan surat keluar serta untuk mengendalikan surat tersebut. 


\section{F. Peraturan Pemerintah Republik Indonesia Nomor 28 Tahun 2012 Tentang Kearsipan}

Pada Pasal 1 Ayat 1 didefinisikan bahwa Kearsipan adalah hal-hal yang berkenaan dengan arsip.. kemudian pada Ayat 2 Arsip adalah rekaman kegiatan atau peristiwa dalam berbagai bentuk dan media sesuai dengan perkembangan teknologi informasi dan komunikasi yang dibuat dan diterima oleh lembaga negara, pemerintahan daerah, lembaga pendidikan, perusahaan, organisasi politik, organisasi kemasyarakatan, dan perseorangan dalam pelaksanaan kehidupan bermasyarakat, berbangsa, dan bernegara.

Pada Pasal 1 Ayat 19 diterangkan bahwa Penyelenggaraan kearsipan adalah keseluruhan kegiatan meliputi kebijakan, pembinaan kearsipan, dan pengelolaan arsip dalam suatu sistem kearsipan nasional yang didukung oleh sumber daya manusia, prasarana dan sarana, serta sumber daya lainnya.

Pengelolaan Arsip Pada Instansi Pemerintah diatur dalam Peraturan Pemerintah Nomor 28 Tahun 2012 pada Pasal 31 dijelaskan bahwa Pasal 31 Pengelolaan arsip meliputi kegiatan:

a. Penciptaan arsip;

b. Penggunaan arsip;

c. Pemeliharaan arsip;

d. Penyusutan arsip.

Pasal 32 Penciptaan Arsip

1. Penciptaan arsip sebagaimana dimaksud dalam Pasal 31 huruf a meliputi kegiatan:

a. pembuatan arsip; dan

b. penerimaan arsip.

2. Pembuatan dan penerimaan arsip sebagaimana dimaksud pada ayat (1) dilaksanakan berdasarkan tata naskah dinas, klasifikasi arsip, serta sistem klasifikasi keamanan dan akses arsip.

3. Tata naskah dinas, klasifikasi arsip, serta sistem klasifikasi keamanan dan akses arsip ditetapkan oleh pimpinan pencipta arsip berdasarkan pedoman yang ditetapkan oleh Kepala ANRI.

Pasal 33

1. Pembuatan arsip sebagaimana dimaksud dalam Pasal 32 ayat (1) huruf a harus diregistrasi.

2. Arsip yang sudah diregistrasi didistribusikan kepada pihak yang berhak secara cepat dan tepat waktu, lengkap, serta aman.

3. Pendistribusian arsip sebagaimana dimaksud pada ayat (2) diikuti dengan tindakan pengendalian.

Pasal 34

1. Penerimaan arsip sebagaimana dimaksud dalam Pasal 32 ayat (1) huruf b dianggap sah setelah diterima oleh petugas atau pihak yang berhak menerima.

2. Penerimaan arsip sebagaimana dimaksud pada ayat (1) harus diregistrasi oleh pihak yang menerima.

3. Arsip yang diterima sebagaimana dimaksud pada ayat (2) didistribusikan kepada unit pengolah diikuti dengan tindakan pengendalian.

Pasal 35

1. Kegiatan registrasi dalam pembuatan dan penerimaan arsip harus didokumentasikan oleh unit pengolah dan unit kearsipan. 
2. Unit pengolah dan unit kearsipan wajib memelihara dan menyimpan dokumentasi pembuatan dan penerimaan arsip.

Pasal 36

1. Pembuatan dan penerimaan arsip harus dijaga autentisitasnya berdasarkan tata naskah dinas.

2. Unit pengolah bertanggung jawab terhadap autentisitas arsip yang diciptakan.

Paragraf 3 Penggunaan Arsip Dinamis Pasal 37

1. Penggunaan arsip dinamis sebagaimana dimaksud dalam Pasal 31 huruf $b$ diperuntukkan bagi kepentingan pemerintahan dan masyarakat.

2. Ketersediaan dan autentisitas arsip dinamis menjadi tanggung jawab pencipta arsip.

3. Pimpinan unit pengolah bertanggung jawab terhadap ketersediaan, pengolahan, penyajian arsip vital, dan arsip aktif

4. Pimpinan unit kearsipan bertanggung jawab terhadap ketersediaan, pengolahan, dan penyajian arsip inaktif untuk kepentingan penggunaan internal dan kepentingan publik.

5. Akses, arsip dinamis dapat dilakukan alih media.

\section{HASIL PENELITIAN}

Pengelolaan arsip dalam penelitian ini lebih ditekankan pada pengelolaan arsip dinamis yaitu suatu proses atau kegiatan dalam suatu organisasi dalam pencapaian tujuan dengan menggunakan sumber daya yang ada, dimulai dari kegiatan penerimaan,

pencatatan, penyimpanan, peminjaman arsip yang bernilai guna bagi organisasi, hingga penyusutan sampai dengan kegiatan pemusnahan arsip yang tidak memiliki nilai guna lagi. Dengan kata lain, pengelolaan arsip dalam penelitian ini lebih berfokus pada daur hidup arsip, yaitu dimulai dari peneriman, pemanfaatan, penyimpanan, penemuan kembali arsip dan disposisiakhir untuk menentukana masa simpan arsip apakah arsip dilestarikan karena mempunyai nilai dimusnakan karena sudah tidak memiliki nilai guna

Ada dua konsep yang digunakan dalam penelitian ini yaitu Implementasi dan manajemen arsip yang bersumber dari Peraturan Pemerintah Republik Indonesia Nomor 28 Tahun 2012 Tentang Kearsipan.

\section{Implementasi}

Menganalisa konsep pertama penulis menggunakan teori Edward III yaitu Komunikasi, Komunikasi berkaitan dengan bagaimana kebijakan dikomunikasikan pada organisasi atau public. Sumber Daya Manusia (SDM) yaitu ketersediaan sumber daya kebijakan. Disposisi yaitu sikap dan respon dari pihak yang terlibat. Stuktur birokrasi yaitu bagaimana struktur organisasi pelaksana kebijakan.

\section{a. Komunikasi}

Menurut Edward III dalam Widodo (2010:97), komunikasi diartikan sebagai "proses penyampaian informasi komunikator kepada komunikan"

Komunikasi berkaitan dengan bagaimana kebijakan dikomunikasikan pada organisasi atau publik. cara mensosialisasikan Peraturan, pegawai di bagian Kasubag Umum dan Kepegawaian melakukan komunikasi secara langsung kepada petugas yang 
mengurus kerasipan untuk menjalankan penataan kearsipan. Kemudian dilanjutkan dengan melakukan komunikasi antar pegawai yang satu dengan pegawai yang lain dan sesuai dengan koridor serta tidak ada kecangungan yang terjadi diantara mereka". (Selasa, 5 Mei 2020).

Berdasarkan Observasi, belum ditemukan adanya himbauan khusus maupun pelatihan khusus penataan kearsipan yang dilakukan untuk Peraturan Pemerintah Republik Indonesia Nomor 28 Tahun 2012 Tentang Kearsipan Di LLDIKTI Wilaah II.

\section{b. Sumber Daya Manusia}

Sumberdaya manusia merupakan salah satu variabel yang mempengaruhi keberhasilan pelaksanaan kebijakan. Edward III dalam Widodo (2010:98)

Berdasarkan hasil penelitian dapat di interpretasikan bahan sumber daya yang ada di LLDIKTI Wilayah II, belum memadai sebab ruang penyimpanan arsip belum rapi dan sarana seperti lemari tempat penyimpanan arsip belum memadai serta belum adanya pegawai khusus kearsipan.

\section{c. Disposisi}

Menurut Edward III dalam Widodo (2010:104) dikatakan sebagai "kemauan, keinginan dan kecenderungan para perlaku kebijakan untuk melaksanakan kebijakan tadi secara sungguh sungguh sehingga apa yang menjadi tujuan kebijakan dapat diwujudkan"

Disposisi adalah aspek yang berkaitan dengan sikap dan dukungan para pelaksana terhadap program atau kebijakan. Sikap dan dukungan sangat penting dalam proses implementasi, karena kesamaan pandangan terhadap apa yang dikerjakan bersama akan mempermudah pencapaian tujuan.

Berdasarkan hasil penelitian diatas, secara garis besar disposisi yang ada di LLDIKTI Wilayah II terlaksana dengan baik sesuai dengan tata urutan dan struktur yang berlaku, serta mematuhi aturan-aturan yang ada dan semua pegawai menerima dan mematuhi ketentuan peraturan yang ada mereka dengan sadar dan tanpa paksaan dari manapun menerima aturan tentang kearsipan, kemudian semua pegawai juga sadar bahwa salah satu faktor yang mempengaruhi efektifitas implementasi kebijakan adalah sikap atau disposisi implementor, jika implemetor setuju dengan bagianbagian isi dari kebijakan maka mereka akan melaksanakan dengan senang hati tetapi jika pandangan mereka berbeda dengan pembuat kebijakan maka proses implementasi akan mengalami banyak masalah.

\section{d. Struktur Birokrasi}

Struktur birokrasi memiliki pengaruh yang signifikan terhadap implementasi kebijakan. Struktur birokrasi berkaitan dengan kesesuaian organisasi birokrasi yang menjadi pelaksana implementasi kebijakan publik. menyatakan Struktur Birokrasi dilakukan dengan melihat kinerja pegawai kemudian disampaikan struktur tersebut pada pertemuan seperti rapat dan sosialisasi dengan pegawai ASN tersebut. (Selasa, 5 Mei 2020).

\section{Manajemen Arsip}

Berikut uraian hasil penelitian dari keempat indikator tersebut

\section{a. Penciptaan Arsip}

Tahap pertama dalam pengelolaan arsip adalah penciptaan. Yang dimaksud dengan penciptaan 
ini adalah penciptaan form baru bagi organisasi, baik form surat, form pengaduan barang, form pemesanan barang, atau form lain yang berhubungan dengan aktivitas organisasi.

Hasil observasi dan dokumentasi penulis bahwa pada

Bagan 2

Alur Arsip

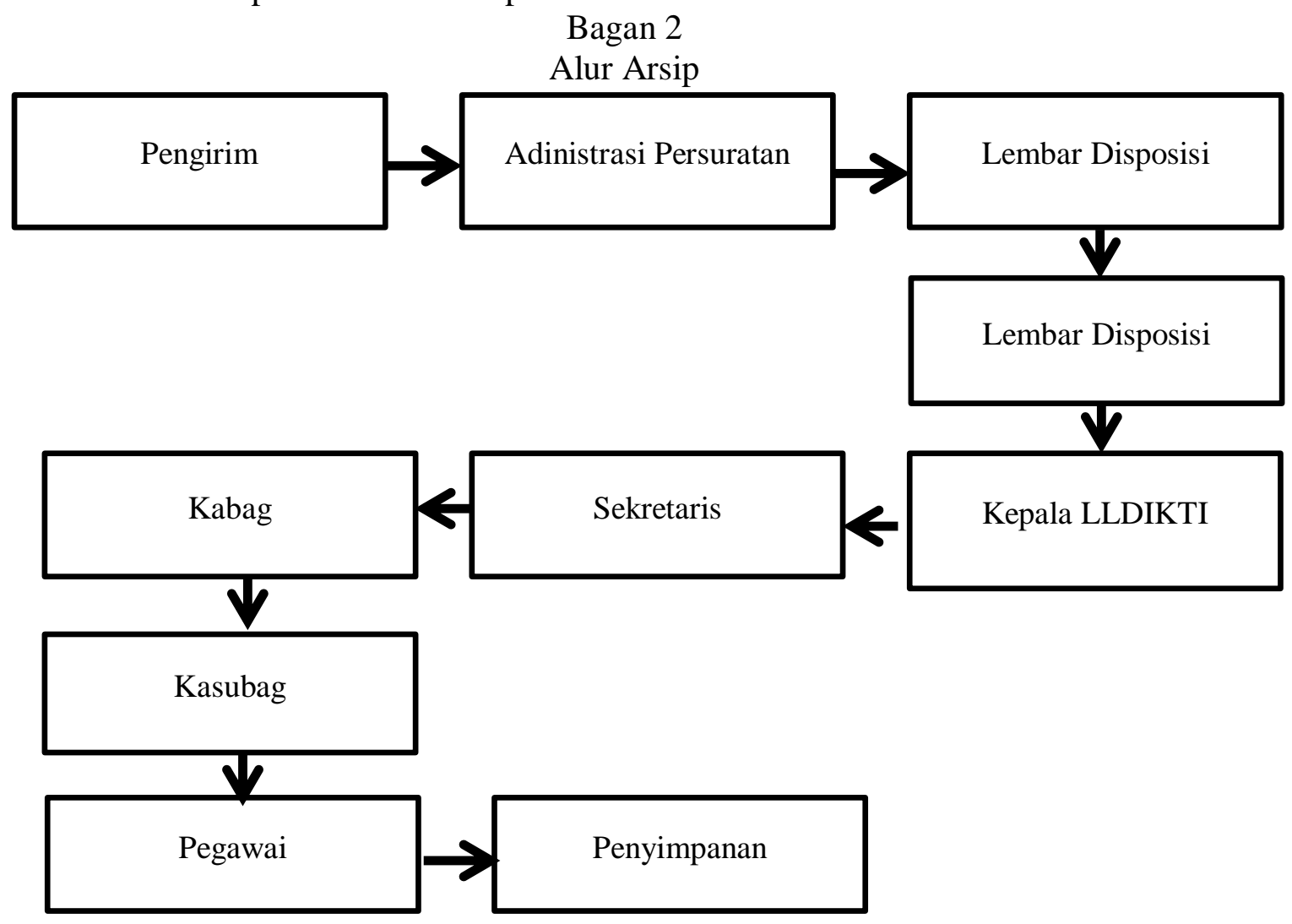

LLDIKTI Wilayah II hanya mempunyai satu orang penata arsip. Sedangkan untuk surat keluar hanya ditugaskan satu orang. Adapun prosedur surat masuk pada LLDIKTI wilayah II dapat dilihat pada bagan dibawah ini:
Dapat di jelaskan bahwa setiap dokumen yang masuk akan dilakukan registrasi sebelum disampaikan kepada pihak yang berhak atau tujuan dokumen tersebut. Dokumen yang masuk harus dilakukan register baik pencatatan tanggal masuk, nomor surat yang masuk, unit tujuan dari dokumen tersebut. Disposisi surat menggunakan dua metode yaitu manual maupun komputerisasi. Pencatatan tersebut bertujuan untuk kepentingan pengarsipan. Namun pada LLDIKTI Wilayah II belum mempunyai ruang arsip sehingga setiap dokumen disimpan pada bagia-bagian tujuan dari dokumen tersebut. Hal ini disebabkan masih belum memadainya tenaga khusus pengarsipan sebab LLDIKTI Wilayah II hanya memiliki 1 orang tenaga Khusus Arsip

\section{a. Penggunaan Arsip}

Tahap kedua adalah pemanfaatan dokumen. Tahapan ini merupakan tahap implementasi dari apa yang telah disusun dan ditetapkan ditahap yang sebelumnya, yaitu bagaimana mengefisienkan proses retrieval maupun pendistribusian arsip kepada pihak yang berkepentingan, termasuk bagaimana pergerakan dokumen yang sangat mempengaruhi kualitas informasi yang dikandungnya.

Berdasarkan hasil penelitian di atas. Dapat di jelaskan bahwa kegiatan pemakaian arsip langsung terhubung kebagian atau unit yang menyimpan 
dokumen tersebut. Hal ini disebabkan belum adanya ruang arsip khusus.

\section{b. Pemeliharaan}

Berdasarkan hasil penelitian di atas. Dapat di jelaskan bahwa setiap arsip yang disimpan akan dierikan kode yang menggabarkan sifat dan jenis dokumen tersebut.

\section{c. Penyusutan}

Dari keempat indikator yang digunakan. Maka dapat dijelaskan bahwa manajemen setiap dokumen yang masuk akan dilakukan registrasi sebelum disampaikan kepada pihak yang berhak atau tujuan dokumen tersebut. Dokumen yang masuk harus dilakukan register baik pencatatan tanggal masuk, nomor surat yang masuk, unit tujuan dari dokumen tersebut. Disposisi surat menggunakan dua metode yaitu manual maupun komputerisasi. Pencatatan tersebut bertujuan untuk kepentingan pengarsipan. Namun pada LLDIKTI Wilayah II belum mempunyai ruang arsip sehingga setiap dokumen disimpan pada bagia-bagian tujuan dari dokumen tersebut. Hal ini disebabkan masih belum memadainya tenaga khusus pengarsipan sebab LLDIKTI Wilayah II hanya memiliki 1 orang tenaga Khusus Arsip. Untuk pengunaan arsip dilakuakn dengan meminjam pada unit yang menyimpan dokumen terseut. Sarana yang digunakan adalah illing cabiet, lemari, komputerisasi dan yang terakhir arsip akan dilakukan penyusutan setelah 5 tahun dengan memperhatikan sifat dari arsip tersebut.

Kearsipanberperanpentingdalamme mbantuterlaksananyatujuanorganisasi, dengan pengelolaan arsip yang baik, maka akan mempermudah organisasi dalam mencapai tujuan yang telah ditetaapkan. Pengelolaan bisa diartikan manajemen, dalam hal ini handoko menjelaskan bahwa manajemen yaitu proses kegiatan yang dimulai dari perencanaan, pengorganisasian, pengarahan dan pengawasan usaha-usaha para anggota organisasi dan penggunaan sumber daya - sumber daya organisasi lainnya agar mencapai tujuan organisasi yang telah ditetapkan (1997). Senada dengan hal tersebut, Siagian menjelaskan bahwa manajemen merupakan kemampuan atau keterampilan untuk memperoleh suatu hasil dalam rangka pencapaian tujauan yang telah ditetapkan sebelumnya dengan menggunakan kegiatan orang lain (2011).

Manajemen Kearsipan adalah prosese kearsipan dari mulai perencanaan, pengorganisasian, pelaksanaan, penyusutan dan pengawasan kearsipan sehingga dapat mewujudkan manajemen kearsipan berjalan dengan baik. Penelitian ini juga bagaimana dalam pemeliharaan kearsipan yang baik supaya arsip terjaga dengan baik sampai arsip itu nantinya kembali dibutuhkan.

Pengelolaan arsip dalam penelitian ini lebih ditekankan pada pengelolaan arsip dinamis yaitu suatu proses atau kegiatan dalam suatu organisasi dalam pencapaian tujuan dengan menggunakan sumber daya yang ada, dimulai dari kegiatan penerimaan, pencatatan, penyimpanan, peminjaman arsip yang bernilai guna bagi organisasi, hingga penyusutan sampai dengan kegiatan pemusnahan arsip yang tidak memiliki nilai guna lagi. Dengan kata lain, pengelolaan arsip dalam penelitian ini lebih berfokus pada daur hidup arsip, yaitu dimulai dari penerimaan, pemanfaatan, penyimpanan, penemuan kembali arsip dan disposisi a khir untuk menentukana masa simpan arsip apakah arsip dilestarikan karena mempunyai nilai dimusnakan karena sudah tidak memiliki nilai guna. Untuk lebih memahami tentang pengelolaan arsip sebagai berikut

1. Pengelolaan arsip adalah penciptaan, yang dimaksud dengan penciptaan ini adalah penciptaan form baru bagi organisasi, baik form surat, form pengaduan barang, form pemesanan barang, atau form lain yang berhubungan dengan aktivitas organisasi. 
2. Pemanfaatan dokumen., tahapan ini merupakan tahap implementasi dari apa yang telah disusun dan ditetapkan ditahap yang sebelumnya, yaitu bagaimana mengefisienkan proses retrieval maupun pendistribusian arsip kepada pihak yang berkepentingan, termasuk bagaimana pergerakan dokumen yang sangat mempengaruhi kualitas informasi yang dikandungnya.

3. Penyimpanan, yaitu bagaimana sebuah dokumen diperlakukan setelah dokumen tersebut dimanfaatkan oleh organisasi. Bila dokumen merupakan dokumen aktid yang frekuensi penggunaanya lebih dari 12 kali dalam setahun, maka perlu diberikan perhatian dalam pemanfaatannya meliputi bagaimana prosedur penyimpanan, penggunaan peralatan filing, mapun tenaga penyimpanan agar menjadi efisien.

4. Retrieval, yang lebih menitikberatkan pada lokasi dokumen maupun arsip yang dimaksud dan melancaknya apabila tidak kembali dalam jangka waktu tertentu. Organisasi harus dapat mengklasifikasikan dokumen dan menentukan lokasi yang tepat dalam penyimpannanya, untuk kemudian mamantau peminjamannya agar petugas arsip dapat memastikan keberadaan semua dokumen yang ada.

5. Disposisi, tahap ini berupa pemeliharaan dokumen yang dianggap penting ke lokasi yang dianggap tepat untuk menyimpannya, termasuk pemusnahan dokumen bila dirasa memenuhi asas cukup untuk dimusnahkan.

\section{Pelaksanaan Pengelolaan Arsip}

Arsip harus dikelola dengan baik agar dapat berfungsi dengan baik dan membantu memperlancar aktivitas organisasi sehingga dapat mencapai tujuan yang ditetapkan. Suatu pengelolaan arsip dapat mencapai tujuan apabila didalamnya terdapat unsur perencanaan (planning), pengorganisasian (organizing), pelaksanaan (actualizing) dan pengontrolan (controling).

Arsip pada dasarnya terdiri dari beberapa macam fungsi yaitu arsip dinamis aktif, arsip dinamis in aktif dan arsip statis serta arsip vital. Demikian pula dalam pengelolaannya terdapat 3(tiga) asas pengelolaan yaitu asas sentralissasi, desentralisasidan gabungan antara sentralisasi dan desentralisasi. Adapun arsip yang ada di LLDIKTI Wilayah II ini meliputi arsip dinamis aktif, in-aktif dan statis, dan dalam pengelolaannya menggunakan asas gabungan sentralisasi dan desentralisasi, yakni arsip dikelola di bagian Tata Usaha dan di bagian yang dituju surat. Semua surat ataupun dokumen yang diterima di LLDIKTI Wilayah II dikelola terlebih dahulu di bagian Tata Usaha Urusan Dalam (TUUD), untuk kemudian dokumen dan surat tersebut diserahkan dikelola lebih lanjut di bagian yang dituju setelah di-copy salinannya untuk arsip di bagian Tata Usaha Urusan Dalam (TUUD).

Mekanisme dalam pengelolaan arsip tersebut adalah sebagai berikut:

\section{Pengurusan Surat Masuk}

Setiap surat atau dokumen dokumen lainnya diterima oleh suatu instansi atau kantor mempunyai nilai sangat berharga, baik sebagai bahan pembuktian(otentik), sebagai alat komunikasi, maupun juga sebagai salah satu pembuktian lainnya yang menunjukkan adanya kegiaatan hidup dalam kantor tersebut. Karena pengurusan surat - surat masuk dan 
keluar harus dikelola dengan sebaik mungkin.

Secara teori, pengurusan surat masuk dimulai penyortiran, pemisahan dan penggolongan surat-surat dan dokumen menurut jenis dan golongannya. Kemudian surat dibuka, untuk diperiksa tanggal dan lampirannya. Setelah isi amplop dikeluarkan, maka surat-surat itu sebelum dicatat dalam buku agenda diberi catatan tanggal surat diterima, hari dan jam penerimaan surat, no agenda, tanggal surat diteruskan, dan tanda tangan petugas. Setelah itu surat dibaca dan diagenda, untuk kemudian diserahkan kepada pimpinan untuk didesposisi. Setalh didesposisi, surat digandakan dan dibagian kepada pejabat yang terkait untuk ditindak lanjuti.

\section{Pengurusan Surat Keluar}

Dalam menindaklanjuti Surat Masuk, ada beberapa surat yang dibutuhkan jawaban yang dibalas. Oleh karena itu diperlukan pembuatan surat.

Adapun proses pengurusan surat keluar di LLDIKTI Wilayah II langkahlangkahnya adalah sebagai berikut :

1) Pimpinan membuat perintah pembuatan surat dan surat dibuat oleh bidang yang ditunjuk.

2) Konsep surat yang telah dibuat dimohonkan persetujuan kepada pimpinan.

3) Surat yang telah ditandatangani pimpinan diberi nomor indeks sesuai nomor urut buku agenda surat keluar dan dicatat di buku agenda keluar.

4) Surat dicopy dan salinannya di Tata Usaha Urusan Dalam(TUUD) sebagai arsip.

5) Surat asli ditempel dan dimasukkan ke dalam amplop.

6) Surat dikirim kealamat yang dituju.

\section{Penyimpanan Arsip}

Arsip memiliki fungsi dan peranan penting dalam menunjang keterlaksanaan dan kelancaran kegiatan organisasi dalam mencapai tujuannya. Oleh karena itu, arsip haruslah disimpan dan dipelihara dengan baik agar apabila sewaktu-waktu dibutuhkan arsip dapat diketemukan dengan mudah,cepat, tepat dan akurat. Penataan dan penyimpanan arsip merupakan suatu kegiatan yang sangat penting dalam pengelolaan arsip. Kegiatan ini tidak sekedar menumpuknumpuk arsip kemudian disimpan tetapi terkait dengan penyimpanan dan penemuan kembali arsip secara sistematis. Dalam penataan dan penyimpanan arsip, terdapat beberapa sistem yaitu sistem abjad, nomor, tanggal, subjek dan geografis.

Pada LLDIKTI Wilayah II, sistem penyimpanan arsip dilakukan dengan menggunakan sistem gabungan, namun tiap bagian mengguanakan sistem gabungan, namun tiap bagian menggunakan sistem yang berbeda sesuai kebijakan bagian masing-masing. Adapun sistem yang digunakan di bagian tata usaha yaitu sistem nomor dan tanggal. Hal ini dapat dilihat setelah surat-surat tersebut diproses, baik surat masuk ataupun surat keluar, salinannya akan segera disimpan ke dalam ordner sesuai dengan nomor urut dan tanggal dari buku agendanya. Kemudian ordner tersebut disimpan. Untuk ordner surat yang masih aktif atau masih dalam 1 tahun berjalan, ordner disimpan dibawah meja, untuk ordner yang berisi arsip berusia 2-5 tahun disimpan di almari arsip dan untuk ordner berisi arsip berusia lebih dari 5 tahun dipindahkan ke gedung arsip untuk kemudian diadakan penyusutan.

\section{SIMPULAN}

Berdasarkan hasil penelitian dan pembahasan di atas dapat disimpulkan bahwa Implementasi Peraturan Pemerintah Republik Indonesia Nomor 28 Tahun 2012 Tentang Kearsipan Pada Lembaga Layanan Pendidikan Tinggi Wilayah II belum terlaksana dengan baik, arsip masih disimpan perbagian hal ini disebabkan 
sumber daya manusia yang ada belum mencukupi dan ruangan khusus arsip belum tersedia.

\section{DAFTAR PUSTAKA}

Basir Barthos. 2009. Manajemen Kearsipan. Jakarta: Bumi Aksara

Basuki, Sulistyo. 2003. Manajemen Arsip Dinamis. Jakarta: PT Gramedia Pustaka Utama.

Dorotul Yatimah. 2009. Kesektariatan Modern dan Administrasi Perkantoran. Bandung: Pustaka Setia

Ida Nuraida. 2007. Manajemen Administrasi Perkantoran, Yogyakarta: Kanisius.

Mutiara, Sikka. Silmi. 2008. Panduan Menulis Surat Lengkap. Yogyakarta: Absolut

Salim, Peter dan Yenny Salim. 2002. Kamus Bahasa Indonesia Kontemporer. Jakarta: Modern English Press.

Soedjito, 2018. Surat Menyurat Resmi. Bandung: Remaja Rosdakarya

Purwanto. 2011. Evaluasi Hasil Belajar. Yogyakarta: Pustaka Pelajar 